The cattle feeder had been cleaned on July 15 and the bird was not there then, so it probably died later in July.

I mailed the bands to Dr. Stuart Houston in Saskatoon, who reported them to the Canadian Wildlife Service in both Ottawa and Edmonton. Harry Armbruster of the C.W.S. office, Edmonton, promptly phoned Dr. Houston with the exciting news that this falcon had been raised in Dr. Tom Cade's captivity breeding program at Cornell University and had been "hacked out" at an artificial nest site in New Hampshire on July 17, 1976, by Dr. F. Prescott Ward.

It did not apparently return to its hacking site, as several others have done, but chose to wander more than 1800 miles west, only to die when little more than one year old.

\title{
LARGE CONCENTRATION OF COMMON NIGHTHAWKS
}

Ken de Graff, Conservation Officer, Waboden, Manitoba, R0B 1S0

On August 8, 1977, at approximately 3:00 p.m., while returning from a trip to the Duck Mountains, my wife and I observed a unique spectacle on No. 10 highway about 20 miles north of The Pas, Manitoba.

We were driving along when suddenly we found ourselves in the middle of what appeared to be hundreds of darting, diving birds. I eased up on the gas pedal because we almost hit several of the birds which were flying only a few feet above the pavement. Large numbers of birds could also be seen a 100 feet or so above the ground.

Identification of the birds was easy due to the large numbers close to the car. The swept-back wings and prominent white wing patch were

unmistakable. These birds we Common Nighthawks. Nighthaw feed heavily on flying insects b insect activity was not obvious an therefore, the reason for such a lar concentration is uncertain.

We proceeded a little farther nor and the commotion ended as sudder as it had begun. Although birds cou still be seen behind us in the rear vie mirror we were out of the flight.

Although I have watched and hea these birds on previous occasior usually in the evening over towns, have never witnessed such a lar concentration before, especially in $t$ middle of the afternoon.

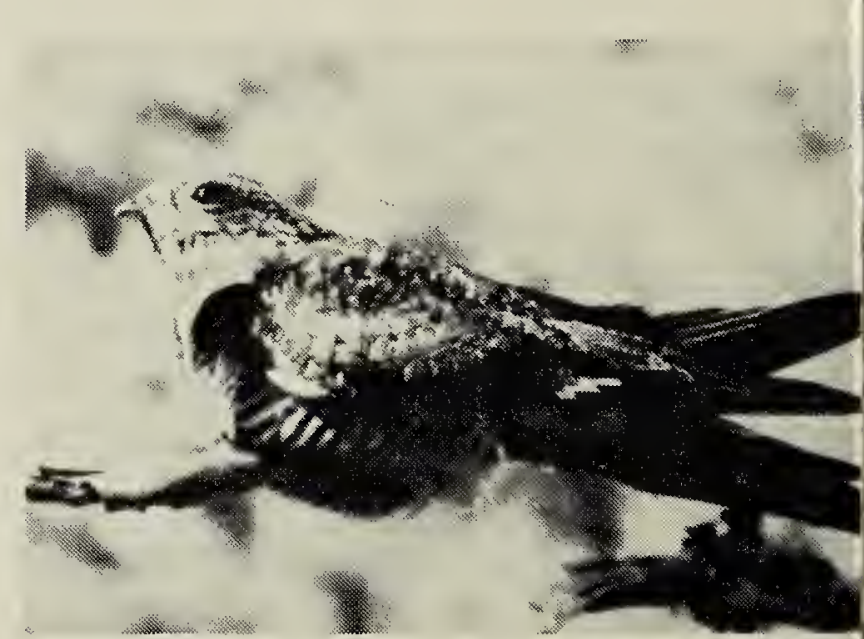

Common Nighthawk

R. E. Gehl

\section{WHITE-FACED IBIS AND CATTLE EGRET AT LITTLE QUILL LAKE}

J. B. GOLLOP, Canadian Wildl Service, Saskatoon, Saskatchewan

Several times in August, 1977, Jo Totten of the U.S. Fish and Wildli Service saw up to seven Cattle Egre and up to four White-faced Ibises the Ding Darling project of Duc Unlimited at the southeast corner Little Quill Lake, Saskatchewan. T egrets were last seen on August 31 a the Ibises on September 1. Mr. Tott was familiar with both species in $t$ United States. 